\title{
The tumour-Clostridium phenomenon: 50 years of developmental research (Review)
}

\author{
WILLI SCHMIDT ${ }^{1,3}$, EVA-MARIA FABRICIUS ${ }^{2,3}$ and ULRICH SCHNEEWEISS ${ }^{3}$ \\ ${ }^{1}$ Department of Bioinformatics, Max-Delbrueck-Center for Molecular Medicine, Robert-Roessle-Strasse 10, \\ D-13125 Berlin-Buch; ${ }^{2}$ Clinic for Oral and Maxillofacial Surgery - Campus Virchow Hospital \\ Medical Faculty Charité, D-13353 Berlin; ${ }^{3}$ formerly Central Institute for Cancer Research, \\ Robert-Roessle-Clinic, Lindenberger Weg 80, D-13125 Berlin-Buch, Germany
}

Received July 10, 2006; Accepted August 24, 2006

\begin{abstract}
The tumour-Clostridium phenomenon describes the specific affinity of spore forming anaerobes to tumour growth. The discovery of strictly intratumoral tetanus toxicoinfections in tumour-bearing mice after intravenous spore administration gave the impulse to search for non-toxic clostridial isolates with tumour-selective properties for clostridial biotherapy, i.e. oncolysis, as well as serologic tumour diagnostics without any toxic side-effects. Systematic studies of the oncolytic process and its variables on diverse experimental tumours and laboratory animals revealed that tumour liquefaction, converting necrotic tumour parts to putrid abscesses filled with masses of clostridial forms, stops sharply at the viable rim of the blood-supplied tumour tissue. Similar results were observed in clinical trials, particular of gliomas. Before oncolysis is initiated, the first stage of clostridial multiplication in the vascularized tissue is inducing a humoural immune response, preceded by phagocytic activity. The majority of tumour-bearing laboratory and domestic animals, so far tested serologically, clinical cancer patients as well, responded with anti-rod antibodies and, independently, antispore antibodies. Oncolytic and non-oncolytic Clostridia were equally immunogenic. During the early, immunizing period of clostridial proliferation, analytical tumour-tetanus experiments were focused on potential relations between tumour growth kinetics and rod proliferation. Based on realistic growth models and target principles, computer simulations could reproduce the results, i.e. cumulative curves of tetanus lethality in groups
\end{abstract}

Correspondence to: Dr Willi Schmidt, Max-Delbrueck-Center for Molecular Medicine, Department of Bioinformatics, Robert-RoessleStrasse 10, D-13125 Berlin-Buch, Germany

E-mail:w.schmidt@mdc-berlin.de

Key words: clostridial oncolysis, clostridial tumour diagnostics, tumour anaerobiosis, tumour selectivity, pacemaker concept, clostridial genetics of mice. Thus, crucial assumptions of the mathematical model were ex post confirmed by further experiments. Our working hypothesis concentrates on temporally hypoxic micro-niches close to a pre-mitotic cell with enhanced oxygen demand which can be utilized by anaerobes (randomly) located there. As early immune reactions to clostridial antigens via phagocytosis and humoural immune response will do without invasion in necrobiotic avascular tumour areas, the pacemaker model of tumour-Clostridium interplay extends the scope of genetically engineered Clostridia to early treatment of metastases. Thus, novel concepts, such as 'Clostridia-directed enzyme prodrugtherapy' and 'Combined bacteriolytic therapy', together with immune activation, can come into play.

\section{Contents}

1. Introduction

2. Experimental approach to clostridial oncolysis

3. Examination of tumour diagnostic facilities

4. Need for analytical experiments and theoretical considerations

5. Two-stage process of biological tumour-Clostridium specificity

6. Non-mathematical description of the pacemaker conception

7. Experimental biotherapy with genetically engineered Clostridia

8. Conclusion

\section{Introduction}

Over five decades, bacteriological research on tumourassociated anaerobic spore forming bacteria has accumulated a considerable amount of information and a variety of new concepts in experimental and clinical oncology. Of great importance was the systematic elucidation which convincingly demonstrated that the growth of anaerobes can be strictly interconnected with tumour growth. This fact revealed certain characteristics of tumour biology which, in the long run, laid the basis for a novel strategy aiming at a selective tumour biotherapy including tumour diagnostics. 
The discovery of the tumour-tetanus phenomenon by Möse (1) and, independently, the 'experimentum crucis' of Malmgren and Flanigan (2) initiated an investigative pattern where the systemic administration of anaerobes resulted in the exclusive and cumulative bacterial multiplication in the tumour site. No previous studies of bacterial effects on neoplasms reported results of the exclusive localization inside the tumorous tissues following the intentional systemic injection of the microbes (3). According to Malmgren and Flanigan, tumour growth with the inherent tendency of cell proliferation, its alteration in the vascular system (4), the dominating anaerobic glycolysis as established by Warburg (5), and the districts of low oxygen tension in necrotic tumour centres (6) appears to fulfill the expected growth requirements for certain species of the genus Clostridium. This concept is in accordance with the basic postulate of the generally accepted necrosis theory of anaerobic infections.

In the Malmgren-Flanigan experiment, mice bearing spontaneous mammary carcinomas, transplanted mammary carcinomas, hepatomas, and fibrosarcomas as well as tumourfree mice as controls were tested with intravenous injections of detoxified spores of Clostridium tetani. All tumour-bearing mice died of tetanus $\sim 48 \mathrm{~h}$ after spore injection preceded by the specific tetanus symptoms. It indicated the germination of the tetanus spores, the replication of the vegetative forms, that is the spore-free tetanus rods, finally the synthesis and secretion of the lethal tetanotoxin. The toxin is distributed in the organism and binding to the spinal cord. Large numbers of vegetative forms of Clostridium tetani were exclusively localized in tumorous areas, predominantly in the necrotic central part of the tumour. All control animals survived without any signs of tetanus. In healthy organs the anaerobic bacteria did not find hypoxic niches which allow their proliferation.

\section{Experimental approach to clostridial oncolysis}

Animal studies. Proceeding from his observation in 1954, Möse recognized the importance of the tumour-tetanus phenomenon for its potential in tumour diagnostics. He started a screening programme intended to identify non-toxic and non-pathogenic clostridial strains to be tested for selective growth in the solidgrowing Ehrlich carcinoma of mice and in subsequent studies for pyrogen-free spores in rabbits. Designated with strain No. 55, Möse and Möse identified Clostridium butyricum, renamed Clostridium oncolyticum, which they isolated from soil (7). It belongs to Clostridium sporogenes ATCC 13732 with an extraordinary oncolytic capability and was found to be the reference strain for further studies. They eventually led to the concept of cancer biotherapy with spore forming anaerobic bacteria. Further investigation revealed anaerobic growth in tumours of various animal species as the basic prerequisite for oncolysis. In contrast to anaerobes, the aerobic spore forming bacteria, genus Bacillus, did not show any oncolysis under comparable experimental conditions (8). In this context, Warburg had realized the Malmgren-Flanigan experiment and clostridial oncolysis as the confirmation of his theory on facultative anaerobic glycometabolism of tumour cells (9). The incongruous state of tumorous growth, that is the three-dimensional proliferation pattern of tumour cells that is not in harmony with the two-dimensional propagation of endothelial cells, leads to the ineffective vascular supply with progressively greater distances of quiescent and necrotizing tumour cells in the increasingly avascular hypoxic tumour areas (10).

In a series of experiments the oncolytic properties of a variety of Clostridia species were tested versus a variety of transplantable tumours in mice, rats, rabbits, and hamsters. A conceptual framework of guiding rules was setup for further practice-related and fundamental studies (11-15). According to the investigators, the beginning of the logarithmic phase of tumour growth in the ascitic form of the Ehrlich carcinoma and of the solid-growing tumour with at least $2 \mathrm{~g}$ of tumour weight proved to be optimal for the administration of Clostridium oncolyticum spores because the partially spontaneous necrosis obviously provides favourable conditions for larger portions of spores to germinate and proliferate (12). Apart from a critical tumour size and the mode of spore injection, spore dose and time-dose relationship between the phases of clostridial propagation would influence colliquative necrosis and resporulation. Additional variables effect the oncolytic potential and extent of the tumour liquefaction, such as the germinative quality of the spores and, last but not least, the host-determined immune reactions. In most cases the animals did not survive extensive oncolysis. A curative outcome after single spore administration was an exception. Generally, the sensitivity of various transplantable tumours differed considerably after oncolytic spore treatment, and in contrast with the predominantly susceptible murine tumours, many rat and rabbit tumours proved to be resistant.

To improve the effect of clostridial oncolysis and to circumvent neoplastic resistance to oncolysis, experiments were started which combined clostridial biotherapy with conventional cytostatic treatment schedules, such as by suitable adjustment of the antimetabolite 5-fluorodeoxyuridine which significantly reduced the average tumour weight below that resulting from the use of either agent alone (13). Noticeably, Gericke and coworkers pointed the way to adjuvant physical modes which turned out to be more successful through local non-curative X-irradiation plus local microwave hyperthermia preceding systemic spore administration. For the first time, a distinct prolongation of life and $20 \%$ total tumour regression were achieved on the transplanted Harding-Passey melanoma of the mouse. Repeated applications of the triple combination therapy were well tolerated with increased cure rates in cases of relapsed tumours (16). Likewise, significant final cure rate and prolongation of complete remission were observed with the triple combination and repeated treatment for recurrence of the oncolysis-resistant methylcholanthrene-induced fibrosarcoma of the mouse (17).

Clinical trials. Before the beginning of preparatory studies for examining patients with advanced neoplasms, safety and side-effects of systemic Clostridium oncolyticum spores were tested in a self-experiment by Möse, starting with a low dose which was increased successively without any adverse reactions. In the clinical approach, single doses of $10^{10}$ spores applied intravenously were well tolerated followed by rising temperature and leukocytosis within 4-8 days which were accompanied by abundant clostridial propagation and progressive oncolysis. The process was comparable with reactions 
a

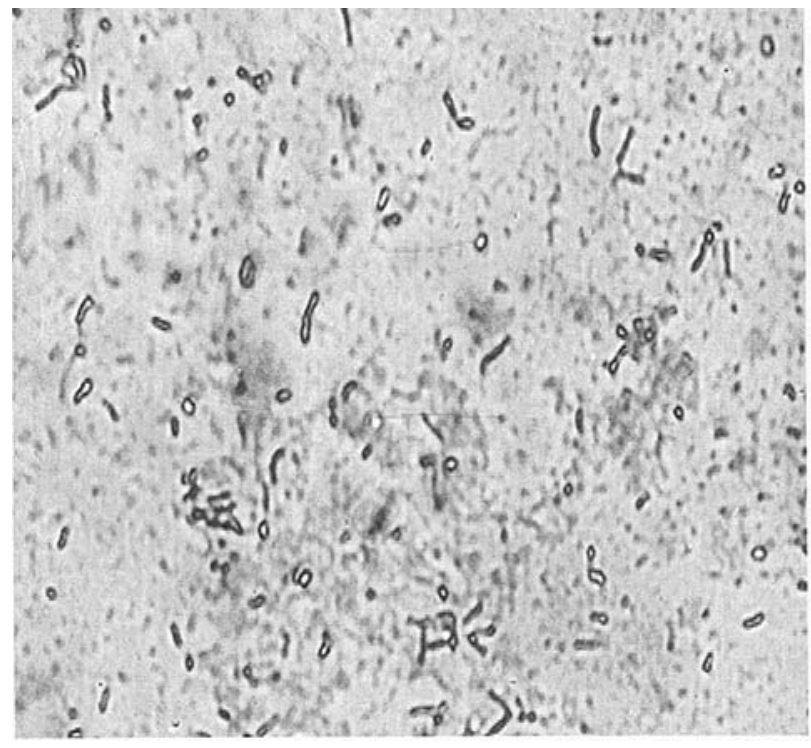

b

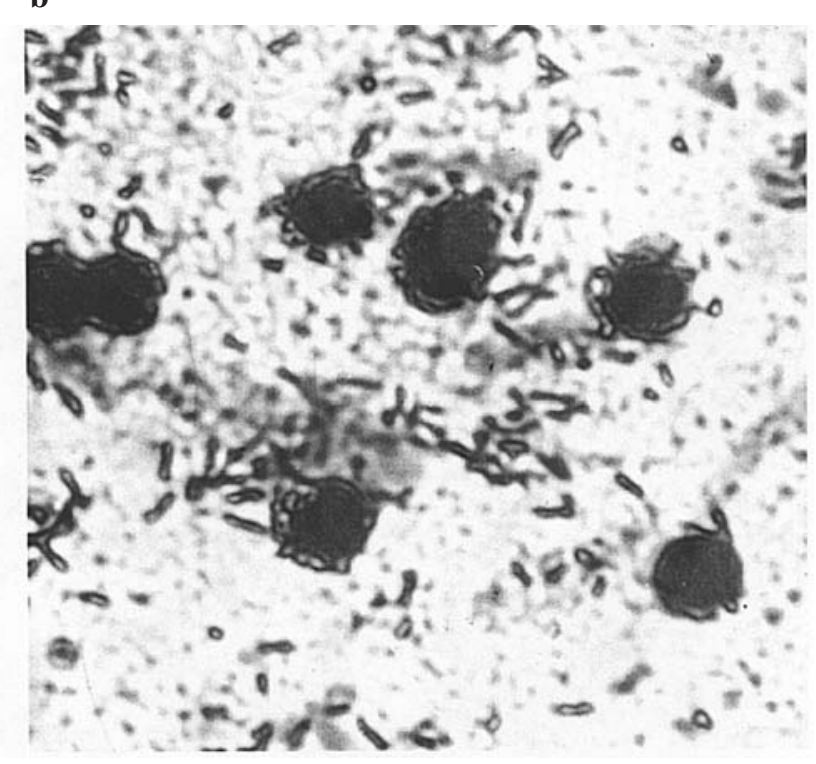

Figure 1. Warburg-manometer experiment with Ehrlich ascitic carcinoma cells and Clostridium butyricum spores $1672 \mathrm{~A}$ (McClung): $10 \mathrm{ml}$ modified ParkerMedium with glucose, bicarbonate and $5 \times 10^{-5} \mathrm{M} \mathrm{Fe}^{++}, 5 \% \mathrm{CO}_{2}$ in $\mathrm{N}_{2}$-atmosphere, 13-h incubation period. (a) $1 \times 10^{7}$ Clostridium butyricum spores $1672 \mathrm{~A}$, (b) $1.8 \times 10^{6}$ viable Ehrlich ascitic carcinoma cells and $1 \times 10^{7}$ Clostridium butyricum spores $1672 \mathrm{~A}$.

in animal tumours, to the extent that partial or total portions of the tumour centre became liquefied converting the necrotic tumour tissue into a putrid abscess, which contained masses of vegetative clostridial rods, sporangia, and mature spores. The oncolysis was interrupted sharply at the border of the viable tumour tissue from which regrowth occurred. The bulk of clostridial rods were to be found in necrotic layers on the viable rim, and repeated spore injections were without any harm (18-21). More information was collected about malignant gliomas. The Clostridium oncolyticum spores were administered by intracarotid injection and the oncolysis was complete one week later. The glioblastoma had converted to a brain abscess which had to be operated appropriately (22). The rate of recurrence remained uninfluenced. Based upon former clinical experience the clostridial oncolysis was strongest in well vascularized gliomas. Daily computertomographic control set the time point for extirpation of the lysed tumour residue. In low grade astrocytomas and poorly vascularized gliomas the spores had little or no effect (23). Altogether, the empirical data of these studies clearly pointed the way towards a restrictive application of oncolytic spores to defined clinical cases of cancer, allowing for balanced water and electrolyte supply with alcalosis control as indispensible means of supportive care (21).

Basic studies. A whole series of experimental studies have been performed to elucidate the mechanisms which governed the selective, temporarily unrestricted clostridial growth and which formed the basis for the liquefaction of tumour tissue. Diverse factors were taken into consideration. Basically, a low partial pressure of oxygen with negative redox potential for the anaerobic energy metabolism of Clostridium oncolyticum (24); despite early vasculogenesis during the incipient invasive phase of tumour cell aggregates (25), the progressive tumour growth which is bearing upon abnormal and insufficient vascular supply in the solid growing tumours gradually outnumbers the process of endotheliogenesis $(26,27)$. Many experimental and human tumours contain poorly vascularized and often necrotic central areas surrounded by a well-vascularized rim of viable tumour cells. This will restrict the oncolytic effects to the hypoxic tumour centres.

Special attention has been addressed to a number of extracellular factors produced either by germinating spores or vegetative forms of Clostridium oncolyticum. Fredette and coworkers gave an account of a cytotoxic factor released from germinating Clostridium oncolyticum spores which selectively inhibited transplantable heteroploid cell lines in distinct proportions of spores to eukaryotic cells, while diploid cell lines remained unchanged $(28,29)$. Similar effects were observed by Schlechte et al (30).

Moreover, several extracellular hydrolases have been found and characterized in supernatants of Clostridium oncolyticum cultures. In particular, the investigation on clostridial kininases (31) and their crucial pharmacophysiologic role in the tumour kinin system leading to diminution and breakdown of the microcirculation via bradykinin degradation (32) has clarified the existence of proteases, peptidases (33), nucleases (34), and phospholipase A (35). The growth curves of Clostridium oncolyticum cultures and their exoenzyme activities showed strict dependence on low redox potential (34).

Apart from clostridial hydrolases connected with oncolysis, it could be proven by manometric technique that under $5 \%$ $\mathrm{CO}_{2} \mathrm{~N}_{2}$ atmosphere metabolizing Ehrlich ascitic carcinoma cells stimulated the germination and replication of Clostridium butyricum 1672 A (McClung) spores in a modified Parker medium. The clostridial growth showed concentric associations with the tumour cell membrane (36): Fig. 1a and b. Even more remarkable were Clostridium oncolyticum rods seen in contact 
with the Ehrlich carcinoma cell membrane, not with normal cells, which were replicating in obvious protection from the mild aerobic milieu after cocultivation in monolayer cell cultures under $1.5 \% \mathrm{O}_{2} 5 \% \mathrm{CO}_{2} \mathrm{~N}_{2}$ atmosphere (30). In a comparable manner and few hours after simultaneous, subcutaneous injection of proliferative tumour cells with mature, viable Clostridium butyricum 1672 A (McClung) spores, both germinative and vegetative forms of Clostridium butyricum could be detected histologically closely associated with mitotic tumour cells of the Ehrlich carcinoma in a disc-like accumulation of viable tumour cells (37). In this context, it is important that Marth and Möse suggested a binding mechanism between Clostridium oncolyticum and tumour cell through the clostridial neuraminidase reaction with $\mathrm{N}$-acetylneuraminic acid (NANA) among the glycolipid pattern of the tumour cell membrane. In consequence, the early rise of NANA in sera of tumour-bearing mice and humans marks an incipient clostridial oncolysis $(38,39)$.

In addition to the tumour-Clostridium interplay during oncolysis between energy metabolism, substance metabolism, and the kinin system, the application of clostridial spores with subsequent multiplication of vegetative rods inside the tumour activates the immune system. On the one hand, immunization with M 55-rod vaccine totally abrogated the oncolytic effect of Clostridium oncolyticum on solid growing Ehrlich carcinoma of mice, while pretreatment of mice with prednisolone significantly enhanced the oncolysis (40). On the other hand, intravenously applied viable spores compared with a single injection into the tumour of live, or heat-inactivated rods, respectively, revealed oncolysis starting at the same time, i.e. $40 \mathrm{~h}$ after inoculation, but with a greater extent of lysis in mice treated with live Clostridia. This pointed to differential influence on oncolysis and the interdependence between immunological and enzymatic mechanisms (41).

\section{Examination of tumour diagnostic facilities}

Experiments on laboratory animals. Due to the antigenic tumour heterogenization (42), the concept of tumour detection became realizable after the discovery of the selective localization of vegetative clostridial forms in the MalmgrenFlanigan experiment (2). Möse had this idea from the beginning and turned to extending his experiments with Clostridium oncolyticum into systematic studies by means of serologic techniques (43). It soon became clear that, after intravenous injection of Clostridium oncolyticum spores, a significant rise of anti-rod antibodies in sera of tumour-bearing mice and other animals is independent of the oncolytic process. Moreover, it could be confirmed that the start of the humoural immune response to the clostridial rod accumulation inside the tumour does occur a few days after tumour transplantation and spore application and clearly before the initiation, or even in absence of oncolysis, respectively. Further essentials for the introduction of clostridial rod antigens into a serologic tumour test were the qualitatively different spore and rod antigens, moreover, the quantitative equivalence of oncolytic and non-oncolytic Clostridia with regard to the criteria of intratumoral immunogenicity (44-46). In particular, the precondition of detectability by the spore assay is the vascularization of the tumour tissue. Aerobic spore forming bacteria, genus Bacillus, are unsuitable. Already in 1965 by using the Widal agglutination and indirect hemagglutination tests, Gericke had described serologic cross-reactions among oncolytic clostridial strains on the one side, and non-oncolytic strains on the other side $(47,48)$. This was confirmed by Sachse and Sachse (49).

When testing transplantable tumours of the rat, after systemic Clostridium oncolyticum spore administration, Kretschmer et al $(50,51)$ observed distinct delays of antibody response against rod antigens following cytostatic treatment with regard to antibody titre dynamics of the untreated control animals and early tumour growth. In another experiment, the anti-rod antibody titre increase signalled ethylnitrosourea induced brain tumours of the rat 2-4 weeks before clinical signs of tumour growth became registered (52).

Schubert and Winkler (53) were the first to investigate the localization of 8-10 days grown Yoshida sarcomas by $\mathrm{I}^{131}$ labelled anti-rod antibodies in rats pretreated with Clostridium oncolyticum spores. The validation of the results by tumour scintigraphy was limited because non-specific intratumoral concentration of nuclide-labelled antibodies in spore-free rats could be demonstrated $(54,55)$. In addition, scintigraphic studies applying oncolytic Clostridia met with difficulties concerning reproducibility of the experiments as the time point of clostridial oncolysis which is most favourable for the intratumoral accumulation of the nuclide-labelled anti-rod antibodies varied and could not definitely be determined. At the peak of clostridial oncolysis peripheral blood vessels became obliterated blocking up the access to the liquefied tumour centre with masses of diverse clostridial forms (39). Further experiments with $\mathrm{Cr}^{51}$-labelled Clostridium butyricum spores revealed preferential spore accumulation in the monocyte-macrophage system, much less in the tumour site (56).

Experimental experience in veterinary medicine. According to Möse (43), Möse and Möse (44), Möse and Gericke (45), tumour-bearing laboratory animals formed antibodies to clostridial rods which could be serologically distinguished from anti-spore antibodies. Absence of anti-rod antibodies in the period of observation following intravenous injection of clostridial spores made the test negative. The test was selectively tumour-reactive against intratumoral multiplying clostridial rods and gave an indirect measure of tumour growth by applying Clostridia serology. The test was more sensitive than Clostridia induced tumour lysis. These findings and the insight which was gained from the analytical tumourtetanus experiments, to be discussed later, initiated the exploration of test facilities in veterinary medicine.

The investigation on spontaneous tumours of the dog anticipated new options for comparative pathology and gave the opportunity to gather experience for clinical studies in human oncology. The dogs were patients of veterinary surgery (57). The tumour was operated 10-14 days after intravenous injection of $2 \times 10^{8}$ Clostridium butyricum spores per $\mathrm{kg}$ body weight. Blood samples were taken before injection, 1-2 weeks, and 2-3 weeks after tumour extirpation.

As the enzyme pattern of Clostridium oncolyticum destroyed tumour tissue with contact sites to cell membranes, with hemolytic effects, and attacked the tumour kinin system at least a local pathologic action could not be denied (35). 
Therefore, careful selection and delineation of clostridial strains for diagnostic purposes in domestic veterinary oncology appeared obligatory. The choice of Clostridium butyricum CNRZ 528 (58) turned out to be suitable and clearly differentiated from Clostridium oncolyticum biologically using the hamster-A Mel 3 assay (59) and biochemically as well as by phage typing (60). Clostridium butyricum (beijerinckii) CNRZ 528 was saccharolytic, non-oncolytic, non-pathogenic, and had been isolated from cheese (61). Its antigenic structure differed qualitatively from Clostridium oncolyticum antigens (62). After successive cloning of Clostridium butyricum CNRZ 528, large batches of rod-free mature spores were prepared for domestic animal trials by the Saxonian Serum Institute Dresden, Branch II at Oelzschau. A total of 251 dogs, 153 with malignant tumours, 59 with benign tumours, and of 39 tumourfree control animals were included in this trial. Many malignant tumours were mammary carcinomas $(46 \%)$. The tumours had been histopathologically evaluated independently from serodiagnosis and vice versa. The final judgement of the spore assay was made by multivariate analysis of the comprehensive serological reaction pattern with the histopathological findings $(62,63)$. The combined evaluation of the complement fixation test and passive hemagglutination test resulted in $80 \%$ test efficiency of the dogs with mesenchymal and mixed tumours displaying more aggressive growth tendency as against $70 \%$ of epithelial tumours.

Despite small numbers of horses, the serologic Clostridiumtumour test rendered a rather satisfactory test result with $66 \%$ positive cancer tests among 9 solid growing malignant tumours and 5 negative tests of the 5 benign neoplasms (64). Injections of $2 \times 10^{8}$ spores per $\mathrm{kg}$ body weight were made into the jugular vein of the animals. A similar study on bovine leukosis virus (BLV)-infected cattle was carried out which belonged to different age groups and stages of infection (with and without hematological alterations) and with incipient tumour development (swelling of externally visible and palpable lymph nodes). Of 6 BLV-infected and spore-treated (6-10 years old) heads of cattle, 3 were spore-test positive and 3 ( $\sim 4$ months old) cows were negative. The cows with positive test were hematologically leukosis-positive with clinically enlarged lymph nodes. By contrast, the 3 negative cows, hematologically leukosis-positive, were without signs of tumorous process. Moreover, 3 spore-treated BLV-free cows and 2 BLVinfected animals with isotonic sodium chloride solution instead of spore treatment were spore-test negative. Finally, 4 BLVinfected and 2 BLV-free cattle, all of them without spore injection, were spore-test negative. In consequence, the early discrimination of tumorous from the non-tumorous BLVprocess lent support to a species-independent experience with serologic Clostridium test-reactivity in veterinary oncology (65). In this context, the examination of 5 green monkeys with 10-fold systemic spore doses, compared to domestic animals, gave further evidence for this argument: One animal was cancer-test positive and had a mesothelioma measuring $\sim 4 \mathrm{~mm}$ in diameter, vascularized, and invading the lung tissue. The spore-test was done in a blind test (66).

Clinical studies. With their 'Clostridial Oncolysis in Man' study, Carey et al (21) had successfully introduced the passive hemagglutination test for examining patients with progressive carcinoma. In the same way, Möse and Möse (67) were able to report increasing anti-rod agglutinin titres of patients with mammary carcinoma following systemic application of Clostridium oncolyticum spores.

As a live diagnostic agent the test spores were subject to drug-testing regulations of the Drug-Act of the GDR (68) as well as to guidelines for testing sera and vaccines (69). Accordingly, tumour lysing clostridial strains were not feasible for diagnostic purposes. In a comprehensive pharmaceuticimmunological protocol, the safety of the test-spores had to be proved on rodents, rabbits, dogs, and green monkeys, while the efficacy of the spores was tested on spontaneous canine tumours $(57,70-72)$. The entire experimental material was submitted to evaluation. An LD50 of Clostridium butyricum CNRZ 528 spores could not be established since the rabbits survived the 100-fold spore doses of the normally used ones in domestic animals, i.e. $2 \times 10^{10}$ spores per $\mathrm{kg}$ body weight. Apart from occasional pyrogenic reactions, the overdoses were without harm. Only histopathology gave reliable judgement of microscopic tissue alterations, such as hepatic resorption granulomas due to excessive spore phagocytosis. The laboratory parameters of hematology and clinical chemistry proved to be of minor informative value in all animal species examined.

The clinical studies were conducted along the lines of the Declaration of Helsinki and after all eligible patients had given a written informed consent: 15 patients of clinical phase I study with stage I and II mammary carcinoma $(n=12)$ and rectum carcinoma $(n=3)$, serum specimen and intravenous dosis of $1 \times 10^{8}$ spores per kg body weight, curative surgery 2 weeks thereafter, and serum specimens 1, 2, 3 weeks postoperatively for antibody titre determination; 62 patients of clinical phase II study with benign colon adenomas $(n=34)$ and cancer monitoring after curative surgery $(n=22)$, moreover mammary carcinoma (1), gastric carcinoma (1), colorectal carcinoma (2), and melanoma (2), $5 \times 10^{7}$ spores per kg body weight, serum specimens for Clostridium-tumour test like clinical phase I study; in addition, 5 patients for clinical phase I study with placebo.

Although spore suspensions were free of pyrogen (73), a spore dose-dependent increase of temperature with $10 \mathrm{~h}$ latency was accompanied by macrophage activation, interleukin-1 secretion, and high acute phase protein CRPlevels (74) as well as spore elimination rates of blood with half-life of $24 \mathrm{~h}$. Patients who received half the spore dose (phase II study) eliminated the spores more slowly with halflife of $48 \mathrm{~h}$ (66). Given a non-specific host defence process by non-thermal components of the fever syndrome, patients of clinical phase I study were prognostically divided into two groups: 2 out of 4 patients with mammary carcinoma and saline solution as placebo had died, while 12 spore-treated mammary carcinoma patients were free of metastases during up to 9 years follow-up.

The complex anti-rod and anti-spore antibody response had to be analysed with a combined set of complement fixation, passive hemagglutination, and IgM-ELISA tests. The total of individual titre values were subjected, by analogy to the clostridial canine tumour serology, to an analysis of discriminance $(62,63)$. According to the protocol, healthy volunteers were not admitted to participate in the study. 
Therefore, final assessment was based on 55 patients with known (malignant and benign) neoplasias at the time of testing. The tumour-Clostridium test achieved $86 \%$ sensitivity and 97\% specificity (75).

While anti-spore antibodies were corresponding to the systemic immune response of the spleen, anti-rod antibodies were locally generated in tumour draining lymph nodes. Thus, two processes of immunization were proceeding independently of each other and the spore-test met the condition of a general biological test for early detection of cancer (76). A positive tumour-Clostridium test was indicative of neoplastic cell growth in the organism with a sufficiently large growth fraction and vascularization, and required an adequately large spore dose for starting intratumorous rod growth. In conclusion, the composition of the physiological bacterial intestinal flora might have been decisive for the emergence of normal anti-rod and anti-spore antibodies as observed in the sera of dogs, horses, and humans, as against the conspicuous absence in sera of cows and green monkeys.

\section{Need for analytical experiments and theoretical considerations}

In the Malmgren-Flanigan experiment intravenously applied spores of Clostridium tetani were distributed throughout the organism, germinated selectively in anaerobic niches of tumours to form vegetative rods, and led to lethal tetanus intoxication of the host. It was a 'black-box' experiment which left three questions unanswered: First, what is the relation between a critical size of tumorous tissue and a distinct quantity of tetanus spores which interact with each other and cause a definable tetanus survival time of the tumour-bearing mice? Second, what distinguishes normal tissue regeneration and tumour cell proliferation with regard to anaerobic growth conditions for Clostridia, in particular for toxigenic Clostridium tetani, and is experimentally calcium chloride-induced wound regeneration comparable with tumour growth to be defined in cumulative tetanus lethality curves? Third, is the presence of necrotizing tumorous tissue a necessary growth condition for clostridial replication, or are proliferating eukaryotic cells which are sufficiently supplied with oxygen and nutrients involved and contribute to clostridial multiplication both in tumour growth and in wound healing?

In analysing the Malmgren-Flanigan experiment spores of Clostridium tetani can be considered as 'probes' for anaerobiosis with the capability of germination, outgrowth, replication, and possibly resporulation. Both steps of anaerobic outgrowth and proliferation are accompanied with synthesis and secretion of powerful tetanotoxin (tetanospasmin) which acts on the synaptic inhibition of motoneurons in the spinal cord $(77,78)$. Mice are reacting to $5 \mathrm{pg}$ of tetanotoxin with specific tetanal symptoms beginning at the site of clostridial propagation. For mice, the lethal dosis of tetanotoxin corresponds to $\sim 100$ viable tetanus rods (79). Spores are resistant to temperature, dessication, chemicals, and radiation. Clostridium tetani Tulloch 3 was used for the analytical experiments. Strain ATCC 8033 (Tulloch 1) of the MalmgrenFlanigan experiment had identical effects.

Experiments with the mouse tumour-tetanus assay. With developing the mouse tumour cell-tetanus spore assay and due to the subcutaneous injection of mixed suspensions with distinct numbers of tumour cells and tetanus spores, it was possible to study in systematic and quantitative experiments the interrelation of proliferating Ehrlich ascitic carcinoma cells and replicating tetanus Clostridia in the triangle of the neckshoulder area. The spores got deposited in close spatial vicinity of viable, mitotic tumour cells (37). Thus, anaerobic clostridial rod growth and toxin secretion could take place in the interstitial space between tumour cells, capillaries, and small blood vessels (35).

At first, the experiments were based on the premise that the early tumour cell proliferation is indicated by the tetanal toxicoinfection. By referring to the main parameters of tetanus incubation period and rate of tetanus incidence it was found that either combination of tumour cells and tetanus spores could lead to $50 \%$ tetanus lethality, namely large numbers of tumour cells versus small doses of tetanus spores and vice versa (80). Given that within certain limits the tumour cells and tetanus spores can be replaced by each other, further experiments supported the evidence that there is a direct correlation between quantity of tumour cell inoculum, early increase of tumour volume, period of tetanus incubation, and incidence of tetanus reactivity. To such an extent, the assumption seemed justified that the growth fraction of the tumour with continued proliferation capacity represented the active foci which provided the anaerobic micro-environment of tetanus Clostridia to multiply and to produce tetanotoxin $(81,82)$. Only those tetanus spores were stimulated to proliferation and toxin production which 'hit' on proliferating clones of tumour cells. Thus, if one considered tumour growth as the consequence of an imbalance between cell birth and cell death of multiplicative cells the tumour-tetanus assay indicated progressive growth kinetics of the tumour stem cells (83).

On another occasion it could be demonstrated that in vitro X-irradiation with 20 Gy of viable Ehrlich ascitic carcinoma cells strongly diminished their power of mitotic growth concomitant with a significant reduction of tetanus reactivity of the mice after subcutaneous injection of the irradiated tumour cells admixed with tetanus spores. It was unexpected that the manometric values of respiration and glycolysis of the 20 Gy-irradiated tumour cells remained unchanged compared with non-irradiated Ehrlich carcinoma cells (84). In an 'experimentum crucis' the cytostatic inhibition of solid growing leukemia L1210 cells in DBA-NMRI hybrid mice prevented the tetanus reactivity without being bacteriostatic in vitro (79). Taken together, the S-shaped temporal course of the tetanus lethality summation curve (start, steepness of slope, termination) always corresponded with the differing growth potential of syngeneic, allogeneic, and xenogeneic tumour cells tested and permitted to analyse the transplantation resistence to tumour growth in mice (82).

Experiments with wound-tetanus of the mouse. The quantitative study of immediate cell replication with tumour-tetanus bore resemblance to the hyperplastic process in wound repair which, according to Haddow, can be identified with controlled tumour growth (85). After taking this line of thought and adopting the subcutaneous injection technique of tetanus spores suspended in $5 \% \mathrm{CaCl}_{2}$-solution (86) as a standard of choice the obtained cumulated tetanus lethality curves of 
mice could equally be related to tetanus incubation time and rate of tetanus incidence. It was noteworthy that the shape of curve runs depended strictly on the number of tetanus spores per dose, on the dose volume of calcium chloride solution, and the body weight (age) of mice. When progressing from dose volume of 0.01-0.1 ml, the tissue impairment leading to wound regeneration was equal to $25 \mathrm{~mm}^{2}$, or $250 \mathrm{~mm}^{2}$ of mean granulation surface, respectively. This specification was valid for mice with 18-20 g of body weight.

According to Hewitt (87), subcutaneously injected particles like transplantable cells or bacteria do not pass through the intact ground substance and collagen mesh but keep adhered at the rim of the traumatized area immediately adjacent to the needle point. This process is one of filtration as the single focus of the tetanus spore-deposit is much smaller than the short-lasting infiltrated area produced. To some extent, the $\mathrm{CaCl}_{2}$-tetanus spore assay of the mouse presented similar experimental conditions as the tumour cell-tetanus spore assay. In both experimental models the outcome of the clostridial growth in loco was influenced primarily by mitotic cells triggered to proliferate, such as transplanted viable tumour cells, or wound granulation fibroblasts, respectively (88).

To distinguish wound-tetanus from tumour-tetanus two groups of mice with equal tetanus lethality rates at the beginning of the experiment were compared under tetanus antitoxin treatment. The passive protection was of $\sim 10$ days duration. Mice with post-sero tetanus were registered exclusively among tumour-bearing mice. Obviously, proliferation of tetanus rods had been sustained by permanently cloning tumour cells (89).

Experiments with normal subcutaneous tissue of the mouse. To re-evaluate the biological background of the MalmgrenFlanigan experiment with tumour-free mice as controls it was essential to study normal subcutaneous tissue showing very low mitotic activity which serves to compensate for homeostatic loss of single cells (90). That explains the problem of extreme tetanus resistance in undamaged subcutaneous tissue. Only very large doses of Clostridium tetani can violate the natural inertness to tetanal toxico-infection of the cell homeostasis maintained by dermal fibrocytes and fibroblasts. For getting 50\% tetanus reactivity in mice single subcutaneous doses of several million tetanus spores suspended in physiological sodium chloride solution were needed (91).

A remarkable biological phenomenon is the physiologic 24-h periodicity involving rhythms associated with the $S$ and M stages of the cell cycle $(92,93)$. To prove the dependence of tetanus reactivity on circadian rhythms in subcutaneous cell homeostasis an extensive experiment was performed on mice after 3 weeks of adaptation to $12 \mathrm{~h}$-light-dark cycles. Twelve groups of mice were injected subcutaneously large equal doses of tetanus spores in successively 6-h intervals each for 3 days and 3 nights beginning at 6 a.m. of day one and ending at 12 p.m. of night three. The outcome demonstrated clearly diurnal rhythms of tetanus reactivity which were reproducible, statistically significant, and in accordance with circadian rhythms in mouse epidermal basal cell epithelium (94). The values of maximum mitotic indices and of tetanus reactivity were increased in the early morning at the beginning of light and on the lowest level after outset of darkness (79). The result of this study might be interpreted as the interrelationship between tetanus spore germination, outgrowth, and replication on the one hand and diurnal mitotic activity of subcutaneous fibroblasts on the other hand.

\section{Two-stage process of biological tumour-Clostridium specificity}

Working hypothesis for stage 'one' in tumour-tetanus infection. Proceeding from the incipient sequential cell divisions immediately after subcutaneous transplantation of tumour cells or $\mathrm{CaCl}_{2}$-induced wound fibroblasts, there was no fundamental difference concerning the concomitant clonal propagation of tetanus rods. The obtained tetanus lethality summation curves of mice resembled each other, with woundtetanus, however, starting and ending earlier. In both growth processes simultaneously administered tetanus spores find anaerobic micro-niches for germination, outgrowth, and rod division. That is a contradictory statement of the theory that tetanus toxicoinfection is strictly dependent on necrotic tissue environment, i.e. almost oxygen-free zones of tissue (95), at least in the initial phase of complex interplay between two non-related live entities as oxygen-dependent malignant or normal cells and peripheral hypoxia demanding tetanus Clostridia. The basic evidence of this process can rather be seen as a natural association between a cell in mitosis, its close vicinity, and its generation of a temporarily hypoxic micro-niche. The true nature of this association has been analysed and characterized in more detail (96).

The working hypothesis can be formulated as follows: In the primary stage of tetanus infection, there is strict dependency on the singularity 'one mitosis - one rod division' under the condition that a clostridial spore has entered the direct environment of a mitotic cell. The rationale behind this hypothesis is that in the mitotic cycle of the cell (tumorous or normal) there is a short interval during which its close environment becomes almost oxygen-deficient. In this way, the cellular environment displays the precondition of a hypoxic microniche which is caused by the high previous oxygen consumption of the pre-mitotic cell. This is sufficient for a clostridial spore germination or division of rod located there. The dependence of the evolution of tetanus toxicoinfection on the growth rate of 'pacemaker cells' has been observed in comprehensive analytical experiments and has been documented in full detail (79).

Experimental evidence for stage 'two' in tumour-tetanus infection. Later, in the secondary stage of tetanus infection, after exceeding a critical length of clonal division steps which depend on the controlling dividing clones of 'pacemaker cells', the propagating tetanus Clostridia may gain access to avascular zones of hypoxic, necrotic tissue. An abundance of tetanus rods will arise which is similar to in vitro growth of anaerobic tetanus cultures. This will almost always lead to death of tetanus.

The substantial base of this inference could be demonstrated in a separate experiment on mice where tumour cells of Ehrlich ascitic carcinoma were applied subcutaneously. The tetanus spores were injected intravenously at day ' 0 ' in a first group of mice and at day ' 10 ' after tumour cell transplantation in a 
$\mathbf{a}$

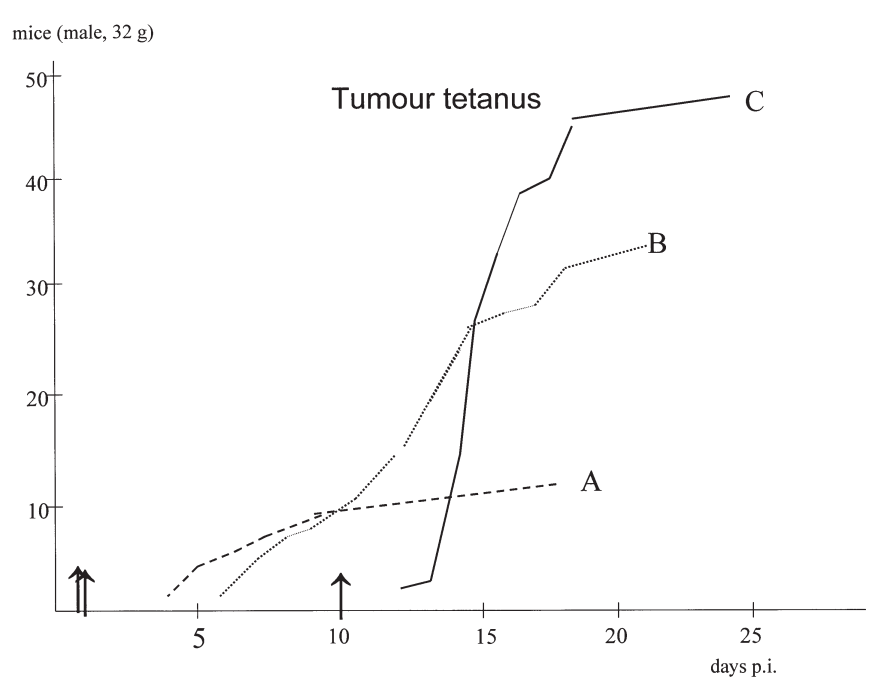

b

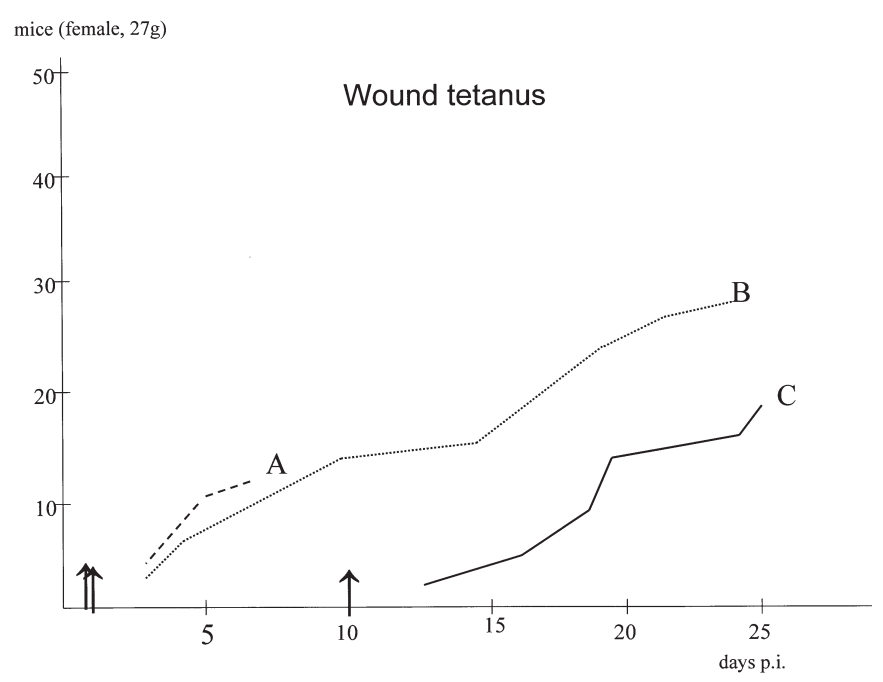

Figure 2. Cumulative tetanus lethality curves following different modalities of spore application. (a) Control group (A) with subcutaneous injection of the tumour cell-tetanus spore suspension $\left(1.3 \times 10^{6}\right.$ cells and 60 spores in $0.1 \mathrm{ml}$ per dose) at day '0'. First test group (B) with subcutaneous tumour cell transplantation $\left(1.3 \times 10^{6}\right.$ cells $)$ and intravenous tetanus spore injection $\left(3 \times 10^{6}\right.$ spores $)$ at day ' 0 '. Second test group (C) with subcutaneous tumour cell transplantation $\left(1.3 \times 10^{6}\right.$ cells $)$ and intravenous tetanus spore injection ( $3 \times 10^{6}$ spores $)$ at day ' $10^{\prime}$. Curve $\mathrm{C}$ represents the abundant mitosis-independent clostridial growth indicating the presence of necrotic regions of the tumour 10 days after transplantation. (b) Control group (A) with subcutaneous injection of the $\mathrm{CaCl}_{2}$-tetanus spore suspension $\left(0.1 \mathrm{ml} 5 \% \mathrm{CaCl}_{2}\right.$-solution and 60 spores per dose) at day ' 0 '. Subcutaneous injection of $\mathrm{CaCl}_{2}$-solution $\left(0.1 \mathrm{ml} 5 \% \mathrm{CaCl}_{2}\right.$ solution) and intravenous tetanus spore injection ( $3 \times 10^{6}$ spores in $0.1 \mathrm{ml}$ per dose) at day ' 0 ' (B). Subcutaneous injection of $\mathrm{CaCl}_{2}$-solution $\left(0.1 \mathrm{ml} 5 \% \mathrm{CaCl}_{2}\right.$ solution) and intravenous tetanus spore injection ( $3 \times 10^{6}$ spores in $0.1 \mathrm{ml}$ per dose) at day ' $10^{\prime}$ ' (C). Curve $\mathrm{C}$ represents the fading away of tetanal proliferation indicating the gradual loss of mitotic wound granulation fibroblasts.

second group. The control group was injected the combined tumour cell-tetanus spore suspension subcutaneously at day ' 0 ' (all groups of mice consisted of 50 animals each): Fig. 2a. The result revealed the mitosis-dependent clostridial growth in a vascularizing micro-tumour from the very beginning of transplantation as clearly marked by the control group. The same course was taken by the first part of the first test group. The rising part of its tetanus lethality curve indicated the successive clostridial colonization in the growing tumour by blood born tetanus spores not yet eliminated through blood clearance from the remaining intravenously injected tetanus spores. It was noticeable that only when the progressive tumour growth had produced avascular tissue districts, the distinctly high and steep course of the cumulative tetanus lethality curve of the second test group became manifested and reflected the clostridial proliferation in the avascular tumour region, independent of mitosis as had been described in the Malmgren-Flanigen experiment.

Fig. 2b gives evidence of a parallel experiment with wound-tetanus under analogous test conditions with tumourtetanus, namely groups and numbers of mice, modalities of injection, point of time, and doses of tetanus spores injected. Instead of tumour cells, $5 \% \mathrm{CaCl}_{2}$-solution was injected subcutaneously. The corresponding tetanus lethality summation curves resembled each other concerning the first test group and the control group. The wound-tetanus curve of the control group started and ended earlier than the tumour-tetanus control group.

A fundamental difference emerged from the cumulative curve of tetanus lethality in the second test group, that is the divergent course of wound-tetanus from tumour-tetanus infection. In contrast to the steep and high tumour-tetanus curve, the wound-tetanus curve tested with intravenously applied tetanus spores at day ' 10 ' (after setting the subcutaneous tissue injury) faded away. This indicated the absence of necrotizing events beyond 10 days in wound granulation tissue and gave reason to point to the 'pacemaking' principle which was effective in wound-tetanus infection throughout the whole observation period of this experiment.

The genome of Clostridium tetani and possible implications. The recently conducted sequencing and decoding of the entire genome of Clostridium tetani (variant of the vaccine producing strain Massachusetts E 88) revealed properties strongly supporting the proposed principle of pacemaker cells $(97,98)$. First of all, in the genetic analysis several potential virulence factors were identified, such as an array of surface-layer and adhesion proteins. Noteworthy are preferences for proteins, peptides, and amino acid degradation pathways as substrates for fermentation. There are primary sodium ion pumps and diverse sodium ion-dependent substrate symporters which give evidence to extensive sodium ion bioenergetics. In this context it is known that methionine, nicotinamide, L-lactic acid, and sodium ions in phosphate-buffered solution are essentials which are involved in spore germination whereby sodium ions are most important (99). Moreover, a heme oxygenase of Clostridium tetani has been characterized. In cooperating with clostridial superoxide dismutase, it could play a role in establishing oxygen tolerance and maintaining reduced anoxic micro-environment. Its weak expression in 
exponential growth and strong expression in the stationary phase of Clostridium tetani might give evidence to an 'up and down' in temporarily aerobic conditions (100). To this extent, the spatial proximity to proliferating eukaryotic cells and their transient increased oxygen consumption might provide optimal conditions for the 'one-to-one' correspondence of the mitotic pacemaker cell and the clostridial rod division.

\section{Non-mathematical description of the pacemaker conception}

The above pacemaker model of clostridial in vivo proliferation [introduced by Schmidt et al (96) and Schneeweiss et al (79)] should, although confirmed by experimental results, be seen as a working hypothesis not yet sufficiently validated and, thus, deserves further attention. To this extent, it is necessary to define the main elements that influence in each particular case the proliferation process of tetanus Clostridia and, thus, the time of outbreak of tetanus in the experimental animal. Note, however, that this process differs from animal to animal despite the fact that identical experimental conditions are used. Therefore, the influential elements must be treated as statistical variables.

Essential parameters of the model. An important variable of the mathematical model is the hit probability p. p measures how many of the tumour cells subcutaneously injected together with the spores reach the direct environment of a mitotic (tumorous or normal) cell allowing the spores to germinate. This number is drawn from certain statistical distribution, that cannot be inferred for each particular case. $p$ depends on the structure of the pacemaker tissue, in particular of its growth fraction, but not on the number of actually injected spores. This number, however, determines the actual number of hits according to the, then, given statistical distribution.

The second central variable of the mathematical model is the cloning probability (denoted by w). w measures the probability that an already completed mitosis-dependent rod division will be followed by (at least) one further step of mitosis-controlled rod division. The number of rod divisions in individual clostridial clones produced by the hit, thus, becomes a random variable with a typical distribution, determined by w. It turned out that the structure of this distribution is different in wound regeneration and for tumour growth. In the latter, $w$ is independent of the generation number, that is, the number of completed generations. This can be explained by the absence of growth regulation. In contrast, for wound regeneration, $w$ depends on the number of generations. This leads to the fact that the number of rod divisions for each clone of a hit has a significantly smaller variance. To describe the number of rod divisions, for wound regeneration the Poisson distribution and for tumour growth the geometric distribution were used. In both cases, $w$ is determined by the inverse of the average number of division steps.

The third group of parameters concerns the cycle times of the pacemaker cells. To describe these, the gamma distribution was used. It is determined by two parameters ( $\alpha$ and $\beta$ ) that are related to the average duration of a cell cycle and its variance $(101,102)$. The temporal evolution of clostridial proliferation in a particular experimental animal is essentially determined by the number of hits, the number of subsequent steps of cloning, and the respective cell cycle durations.

Whether, and when tetanus disease breaks out in each particular case depends on the toxin sensitivity of the animal. It is assumed that there is a certain critical toxin level that corresponds to a critical number of rods $(\mathrm{K})$. $\mathrm{K}$ is another parameter of the model that was estimated from experimental data (96).

The parameters $\mathrm{p}, \mathrm{w}, \alpha, \beta$, and $\mathrm{K}$ are, thus, the central determinants of the pacemaker model. They should be able to describe qualitatively and quantitatively the temporal course of the untreated clostridial proliferation, in particular the cumulative tetanus diseases in the experimental animals, given that the pacemaker concept is indeed correct. Furthermore, the model should yield correct predictions when therapeutic measures are used, such as penicillin against rod growth, or tetanus antitoxin to neutralize tetanus toxin. Using appropriate extensions, the model has successfully been used $(103,104)$.

Application of the pacemaker model to experimental data. A mathematical model of a biological process is a theoretical working hypothesis and cannot capture all aspects. Essential is the postulate to include the main aspects and driving forces of the process. If the model fulfills this criterion, it can be used to analyse data and draw further conclusions. Deficiencies of the model are revealed when it leads, for some experimental results, to obvious contradictions. The pacemaker model is based on stochastic concepts (probabilities and distributions). For its realization and validation, the Monte-Carlo methods were used. This means that the course of clostridial proliferation in each experimental animal is considered a realization of the stochastic pacemaker process and is computationally verified. In each case, the experimental details must be specified: number of spores applied, cell type (tumour growth or wound regeneration), sample size, temporal scheme, quantity of additional antitoxin, antibiotics, cytostatic therapy if it was applied. At the beginning of a simulation, for each parameter of the model, approximate values are specified. A particular 'experiment' with a sample size of 50 animals simulated on the computer, then, corresponds to 50 realizations of the stochastic process as defined by the model. The result is a cumulative tetanus lethality curve that can be compared with the corresponding experimental curve. As any single comparison of this type is obviously insufficient, the computer programme produces numerous curves of this type, with the aim to reproduce the experimental curve as an average curve of the simulated curves (compatibility). If this is not achieved using the initial parameter specifications, the parameters are re-adjusted until compatibility is reached. In this way, for instance, the distribution of cell cycle durations can be estimated (using the parameters $\alpha$ and $\beta$ ). It can be double-checked using other, independent methods, e.g. autoradiographic analysis of the corresponding tumour cell population. At the same time, the possibility of achieving compatibility using realistic parameter values, and the ability of the model to predict the outcome of experiments under alternative, not yet tested conditions are used as criteria to evaluate the correctness of the main assumptions of the model. 
Conclusive evidence of the pacemaker model. The main conclusion from foregoing experimental investigations, proceeding from the results of the Malmgren-Flanigan experiment, was, that at least during the initial phase of clostridial proliferation in warm-blooded organisms, a specific, not yet generally accepted mechanism must be at work. This mechanism enables Clostridia to utilize the energy metabolism of proliferating eukaryotic cells for their own growth. On the one hand, due to their increased oxygen consumption, the host cells produce in their environment temporarily and spatially limited hypoxic niches. On the other hand, according to new insights based on genome analyses of Clostridium tetani, Clostridia are able to home in on these niches by their own metabolic activity, which enables them to utilize the respective tissue for their proliferation, even when there is a sufficient supply of oxygen. That does not exclude intensified clostridial multiplication in a later stage, based on tissue hypoxia and developing necrosis due to insufficient oxygen supply. However, homing is likely to be a necessary precondition since intravenously applied spores scarcely reach existing avascular tissue areas.

These conclusions were based on a large number of animal experiments. It led to the working hypothesis that was translated into a stochastic model which, in turn, could be analysed using a computer programme. This allowed to confront theoretical predictions stemming from the model with the experimental results, and to determine the main parameters of the model. The analysis showed a high degree of compatibility $(96,103,104)$.

\section{Experimental biotherapy with genetically engineered Clostridia}

Since tumour lysis with Clostridium oncolyticum spores is incomplete and, possibly, subject to non-specific systemic incompatibility ['acute tumour lysis syndrome' (105)], the genetic engineering with specific transforming protocols for Clostridia became significant in pursuing the concept of engineered Clostridia to produce anti-cancer drugs (106-108). In 1988, Schlechte and Elbe were the first who attempted the transformation of Clostridium oncolyticum with an Escherichia coli plasmid-derived gene encoding colicin E3, a bacteriocin with cancerostatic properties (109). Meanwhile, various research groups have successfully engineered several Clostridium species to producers of proteins in anti-tumour therapy (110).

Clostridia-directed enzyme prodrug-therapy (CDEPT). In the eighties, advances in Clostridia genetics made gene manipulations of Clostridia available and created the novel concept of CDEPT by Brown, Minton, and coworkers (111). At first, the saccharolytic strain Clostridium acetobutylicum (beijerinckii) and later the proteolytic strain Clostridium sporogenes were used to produce an enzyme which can metabolize a systemically applied non-toxic product into a cytotoxic metabolite at the tumour site, to a large extent sparing healthy tissues and organs. The Clostridia were transformed with a recombinant plasmid carrying the Escherichia coli gene for encoding the enzyme.
In a first successful experiment, a clone of Clostridium sporogenes which is closely related to Clostridium oncolyticum and carrying a recombinant plasmid with the Escherichia coli gene encoding the bacterial enzyme cytosine deaminase (CD) could be tested with tumour-bearing mice. This enzyme can convert the systemically applied non-toxic prodrug 5-fluorocytosine (5-FC) to the anti-cancer drug 5-fluorouracil (5-FU) after intravenously injected recombinant clostridial spores had yielded high efficiency of tumour colonization which remained undiminished 14 days after a single injection of spores. A significant growth delay of the tumours was achieved by 5 times a week systemic injections of 5-FC. The tumour extract from recombinant spore-treated mice increased the in vitro cytotoxicity of 5-FC for tumour cell cultures by the factor of $10^{3}$. This anti-tumour effect was greater than with 5-FU alone (112). The efficient turnover of 5-FC carried out by the Escherichia coli CD could be seen as an essential step toward the tumour targeting strategy with clostridial recombinant spores as selective delivery vectors $(113,114)$.

A further approach to increase the spatial and temporal specificity of the therapeutic proteins, such as cytosine deaminase or murine tumour necrosis factor $\alpha(115,116)$, was the introduction of a radio-inducible promoter-regulation. Thus, putting the expression of the recombinant genes under the inducible DNA-repair genes (SOS-repair) via irradiation with 2 Gy into action means a temporal and spatial delivery of the tumour-noxious agents in question. This will bring an increase of therapeutic ratio and, in a way, become advantageous to the classical gene therapy (117). It enables to deliver the dose at the target tissue with specific activation of the recombinant genes and presents a novel therapeutic modality to deliver anti-cancer agents specifically in space and time to the tumour site.

The crucial question of efficient colonizing tumours of smaller size $\left(<3 \mathrm{~cm}^{3}\right)$ has been adressed with experiments using vascular targeting compounds combined with the vector system 'Clostridium sporogenes' to be tested in syngeneic rat rhabdomyosarcomas after both Clostridium acetobutylicum and Clostridium oncolyticum, following systemic administration, had displayed superior colonization capacity $(118,119)$. Among smaller tumours of $<1 \mathrm{~cm}^{3}$ there were such with little hypoxia and no necrosis. A significant improvement of tumour colonization was obtained, scored in clostridial colony forming units, and showing strict relationship to the extension of necrosis due to the action of the vascular targeting compound.

Combination bacteriolytic therapy (COBALT). A prospective, though daring step has been taken by selecting a strain out of gas gangrene Clostridia, Clostridium novyi, by removing the lethal $\alpha$-toxin gene from the wild-type strain through heating the spores to inactivate the phage gene carrying the toxin. Of 400 clostridial colonies screened 3 had lost the toxin gene: Clostridium novyi-NT. Large numbers of spores injected intravenously into mice were without side-effects, while abundant intratumoral growth led to hemmorhagic necrosis exclusively in tumour tissue (120). Both syngeneic mouse B16 melanomas and xenogeneic human colorectal carcinomas with nude mice showed tumour cell killing adjacent to the necrotizing tumour centres in direct vicinity of germinating spores. 
Experimental bacteriolytic radiation therapy. To overcome tumour hypoxia related resistance to radiation therapy, combination with Clostridium novyi-NT treatment appeared feasible since intratumoral crowding of multiplying Clostridia eliminated those tumour components that are least sensitive to radiation due to poor oxygenation. In traditional radiation therapy tumour sensitivity is inversely correlated to tumour size. It turned out that the efficacy of combined bacteriolytic radiation therapy was not a function of tumour volume (ranging from $50 \mathrm{~mm}^{3}$ to $1000 \mathrm{~mm}^{3}$ ) and immune status because both syngeneic mouse B16 melanoma and xenogeneic human tumour cell lines with immunocompromised nude mice showed significantly improved results of radiotherapy through selective clostridial destruction of hypoxic tumour districts (121).

Thus, Clostridium novyi-NT treatment was enhancing local modes of radiation with external beam radiation of a $\mathrm{Cs}^{137}$ source (a total of 5 daily doses of 2 Gy each), or even more effective, with experimental brachytherapy using $\mathrm{I}^{125}$ 'OncoSeeds', respectively. In order to treat systemic disease, radio-immunotherapy with $\mathrm{I}^{125}$ and $\mathrm{I}^{131}$ conjugated monoclonal anti-CEA antibodies (from a myeloma clone secreting anticarcinoembryonic antigen monoclonal antibody) could be applied. Clostridium novyi-NT spores were effective before or after injection of labeled antibodies. Of 14 nude mice carrying xenogeneic human colorectal adenocarcinoma two were cured, whereas all mice treated with radio-immunotherapy alone were subjected to excessive tumour growth. These data from various forms of radiation therapy suggested that Clostridium novyi-NT application can potentiate standard radiation regimens.

Bacteriolytic therapy and immunity. Notable were tumour experiments conducted on syngeneic Balb/c mice and allogeneic New Zealand rabbits that yielded ca. $30 \%$ cure rate of animals after sole and single treatment with Clostridium novyi-NT spores, despite viable rims of tumour cell, initially remaining after intratumoral spore germination and massive vegetative growth (122). Even large tumours completely regressed: murine colorectal and renal carcinoma cells, injected subcutaneously; rabbit VX2 minced tumour material, inoculated intrahepatically. The initial accumulation of inflammatory neutrophils at the tumour periphery was followed, within a few days, by monocytes and lymphocytes. Adoptive transfer experiments determined $\mathrm{CD}^{+}$cells responsible from mice cured with Clostridium novyi-NT application. Similar to adjuvants, the infection with Clostridium novyi-NT, devoid of lethal $\alpha$-toxin, stimulated an inflammatory response with neutrophil-directed cytokines leading to a potent cellular antitumour immune response.

\section{Conclusion}

The pacemaker model yielded important insights that can be used for future development in the field of cancer diagnostics and therapy after recent research on Clostridia has led to advances in Clostridia genetics and its biotechnological exploitation. As its working principle determines the first stage of clostridial multiplication in the tumour and is accompanied by anti-Clostridia induced immune reactions, the scope for approaches to treatment and diagnostic modalities of early stages of cancer and metastases should be envisaged. Existing applications in the experimental field, fitted with tumour-specific supplements, are based on the precondition that the tumours to be treated have pronounced hypoxic tissue regions for mass production of Clostridia. If it must be assumed that abundant hypoxic tumour areas are not essential for clostridial reproduction, novel strategies, such as 'Combined bacteriolytic therapy' coupled with antiClostridia immune activation will come into play.

\section{References}

1. Möse JR: Das Clostridien-Tumorphänomen. Zentralbl Bakteriol I Abt Ref 240: 343-345, 1974.

2. Malmgren RA and Flanigan CC: Localization of the vegetative form of Clostridium tetani in mouse tumors following intravenous spore administration. Cancer Res 15: 473-478, 1955.

3. Reilly HC: Microbiology and cancer therapy. Cancer Res 13: 821-834, 1953.

4. Tannock IF: The relation between cell proliferation and the vascular system in a transplanted mouse mammary tumour. Br J Cancer 22: 258-273, 1968 .

5. Warburg O: The Metabolism of Tumours. Constable and Co. Ltd., London, 1930.

6. Thomlinson RH and Gray LH: The histological structure of some human lung cancers and the possible implication for radiotherapy. Br J Cancer 9: 539-549, 1955.

7. Möse JR and Möse G: Onkolyseversuche mit apathogenen anaeroben Sporenbildnern am Ehrlich-Tumor der Maus. Z Krebsforsch 63: 63-74, 1959.

8. Möse JR: Zur Beeinflußbarkeit verschiedener Tiertumoren durch einen apathogenen Clostridienstamm. Z Krebsforsch 63: 447-455, 1960 .

9. Warburg O: Über die fakultative Anaerobiose der Krebszellen und ihre Anwendung auf die Chemotherapie. Münch med Wochenschr 103: 2504-2506, 1961.

10. Vaupel P: Atemgaswechsel und Glucosestoffwechsel von Implantattumoren (DS-Carcinosarkom) in vivo. Akademie der Wissenschaften. Klasse für Literatur und Math-Nat Mainz. Funktionsanalyse Biol Systeme 1: 5-138, 1974.

11. Möse JR and Möse G: Oncolysis by clostridia. I. Activity of Clostridium butyricum (M-55) and other nonpathogenic clostridia against Ehrlich carcinoma. Cancer Res 24: 212-216, 1964.

12. Gericke D and Engelbart K: Oncolysis by clostridia. II. Experiments on a tumor spectrum with a variety of clostridia in combination with heavy metal. Cancer Res 24: 217-221, 1964.

13. Thiele EH, Arison RN and Boxer GE: Oncolysis by clostridia. III. Effects of clostridia and chemotherapeutic agents on rodent tumors. Cancer Res 24: 222-233, 1964.

14. Thiele EH, Arison RN and Boxer GE: Oncolysis by clostridia. IV. Effects of nonpathogenic clostridial spores in normal and pathological tissues. Cancer Res 24: 234-238, 1964.

15. Engelbart K and Gericke D: Oncolysis by clostridia. V. Transplanted tumors of the hamster. Cancer Res 24: 239-242, 1964.

16. Gericke D, Dietzel F, König W, Rüster I and Schumacher L: Further progress with oncolysis due to apathogenic clostridia. Zentralbl Bakteriol Hyg I Abt Orig A 243: 102-112, 1979.

17. Gericke D, Dietzel F and Pirlet T: Oncolysis by clostridia in induced and transplanted experimental tumours. In: ClostridiumTumour-Phenomenon. Gericke D, Möse R and Schneeweiss U (eds). Proceedings of the 13th International Congress of Chemotherapy. Spitzer KH and Karrer K (eds). 226: 11-26, 1983.

18. Carey RW: Clostridial oncolysis in man. Proc Amer Ass Cancer Res 6: 10, 1965.

19. Heppner F and Möse JR: Onkolyse maligner Gliome durch apathogene Clostridien. Zentralbl Neurochirurgie 27: 184-192, 1966.

20. Möse JR, Möse G, Propst A and Heppner F: Onkolyse maligner Tumoren durch den Clostridienstamm M55. Med Klinik 62: 189-225, 1967.

21. Carey RW, Holland JF, Whang HY, Neter E and Bryant B: Clostridial oncolysis in man. Eur J Cancer 3: 37-47, 1967.

22. Heppner F and Möse JR: The liquefaction (oncolysis) of malignant gliomas by a non-pathogenic clostridium. Acta Neurochir (Wien) 42: 123-125, 1978. 
23. Heppner F, Möse JR, Ascher PW and Walter G: Oncolysis of malignant gliomas of the brain. In: Clostridium-TumourPhenomenon. Gericke D, Möse R and Schneeweiss U (eds). Proceedings of the 13th International Congress of Chemotherapy. Spitzer KH and Karrer K (eds). 226: 38-45, 1983.

24. Kaiser D: Über die Messung des Sauerstoffdruckes, bei dem Sporen von Clostridium butyricum auskeimen. Z Naturforsch 17b: 658-660, 1962.

25. Folkman J: Tumor angiogenesis factor. Cancer Res 34: 2109-2113, 1974.

26. Folkman J and Cotran R: Relation of vascular proliferation to tumor growth. Int Rev Exp Pathol 16: 207-248, 1976.

27. Vaupel $\mathrm{P}$ and Thews G: $\mathrm{PO}_{2}$ distribution in tumor tissue of DS-carcinosarcoma. Oncology 30: 475-484, 1974.

28. Rousseau P, Chagnon A and Fredette V: The effect of anaerobic spores on animal cell cultures. Cancer Res 30: 849-854, 1970.

29. Chagnon A, Hudon C, McSween G, Vinet G and Fredette V: Cytotoxicity and reduction of animal cell growth by Clostridium M55 spores and their extracts. Cancer 29: 431-434, 1972.

30. Schlechte H, Baumbach L and Elbe B: Cocultivation of Clostridium oncolyticum with normal and tumour cell lines. Arch Geschwulstforsch 51: 51-57, 1981.

31. Möse JR, Fischer G and Mobascherie TB: Über Bakterienkininasen und deren physiologischer Bedeutung. I. Mitt: Untersuchungen an Clostridienstämmen. Zentralbl Bakteriol Hyg I Abt Orig A 219: 530-541, 1972.

32. Fischer G, Brantner $\mathrm{H}$ and Platzer P: The kininase activity of Ehrlich's ascites solid tumour after treatment with oncolytic clostridia. Z Krebsforsch 84: 203-206, 1975.

33. Brantner H and Schwager J: Enzymatische Mechanismen der Onkolyse durch Clostridium M55 ATCC 13732. Zentralbl Bakteriol Hyg I Abt Orig A 243: 113-118, 1979.

34. Haller E-M and Brantner H: Enzymologische Untersuchungen am Clostridium oncolyticum M55 ATCC 13732. Zentralbl Bakteriol Hyg I Abt Orig A 243: 522-527, 1979.

35. Brantner $\mathrm{H}$ and Schwager J: A theoretical model of oncolysis by Clostridium oncolyticum M55 ATCC 13732. Arch Geschwulstforsch 50: 601-612, 1980.

36. Negelein E, Schneeweiss U and Fabricius E-M: Versuche zur Stimulierung des Klostridienwachstums (Clostridium butyricum 1672 A, McClung) durch den anaeroben Stoffwechsel von Ehrlich-Aszites-Karzinomzellen der Maus. Arch Geschwulstforsch 45: 111-120, 1975.

37. Urban S, Wildner GP, Schneeweiss U and Fabricius E-M: Das Verhalten von Clostridium butyricum im frühen EhrlichKarzinom - Experimentelle Untersuchungen zum TumorKlostridien-Phänomen. Arch Geschwulstforsch 43: 8-15, 1974.

38. Marth E and Möse JR: Oncolysis by Clostridium oncolyticum M55 and subsequent enzymatic determination of sialic acid in serum. Zentralbl Bakteriol Hyg A 265: 33-44, 1987.

39. Marth E, Ascher WP, Pavelka R and Möse JR: Tumor lysis of a glioblastoma by Clostridium oncolyticum. J Chemotherapy 1 (Suppl 4): 1177-1178, 1989.

40. Schweizer K: Der Einfluß der Immunabwehr auf den onkolytischen Effekt von Clostridium butyricum. Z Immunitätsforsch 142: 455-467, 1972.

41. Haller E-M: Enzymologische Untersuchungen zur Onkolyse durch Clostridium oncolyticum M55 ATCC 13732. Thesis, Universität Graz, 1979.

42. Svet-Moldavsky GJ and Hamburg VP: Quantitative relationships in viral oncolysis and the possibility of arteficial heterogenization of tumours. Nature 202: 303-304, 1964.

43. Möse JR: Versuche zu einer serologischen Tumordiagnostik mittels sporenbildender Bakterien. Z Krebsforsch 73: 329-341, 1970.

44. Möse JR and Möse G: Versuche zu einer serologischen Tumordiagnostik mittels sporenbildender Bakterien II. Z Krebsforsch 74: 91-99, 1970.

45. Möse JR and Gericke D: Versuche zu einer serologischen Tumordiagnostik mittels sporenbildender Bakterien (III). Z Krebsforsch 76: 83-90, 1971.

46. Schwager J and Brantner H: Immune electron optical examinations of the cell wall antigens of oncolytic clostridia. Zentralbl Bakteriol Hyg I Abt Orig A 242: 245-260, 1978.

47. Gericke D: Über einige serologische Untersuchungen an apathogenen Clostridien. Zentralbl Bakteriol Hyg Abt I Orig 195: 392-397, 1965.
48. Gericke D and Vértesy L: Serologische Untersuchungen mit apathogenen Clostridien (M55). Zentralbl Bakteriol Hyg Abt I Orig 232: 303-307, 1975.

49. Sachse H and Sachse R: Versuche über Hämosensitine aus Clostridium butyricum. Z gesamte Hygiene 23: 759-762, 1977.

50. Kretschmer H, Hambsch K and Ludewig R: ClostridienAntikörper-Verhalten bei Ratten mit Transplantationstumoren unter Zyklophosphamid-Therapie. Arch Geschwulstforsch 44: 103-105, 1974.

51. Kretschmer H, Schöche J and Gräßer A: Serologische Untersuchungen mit Clostridiensporen zur Tumordiagnostik. II. Untersuchungen an Äthylnitrosoharnstoff-induzierten Tumoren bei Ratten. Arch Geschwulstforsch 41: 114-119, 1973.

52. Kretschmer H, Hambsch K, Ludewig R and Gräßer A: Serologische Untersuchungen mit Clostridiensporen zur Tumordiagnostik. III. Versuche zum Tumornachweis in frühen Wachstumsphasen am Jensen-Sarkom der Ratte. Arch Geschwulstforsch 44: 100-102, 1974.

53. Schubert RHW and Winkler C: Selektive Radioaktivitäsanreicherungen in Tumoren. Fortschr Med 83: 351-352, 1965.

54. Winkler C: Über die Nutzung gerinnungsphysiologischer und immunologischer Prozesse zur Radioaktivitätsanreicherung in Tumoren. In: Radionukleide in der Klinischen Experimentellen Onkologie. 2. Jahrestagung der Gesellschaft für Nuklearmedizin in Heidelberg 1964. Schattauer FK (ed). Stuttgart, pp349-359, 1965.

55. Schubert RHW: Über die Anreicherung radioaktiv markierter Clostridienantikörper in Tumoren mit Clostridien-Sporen vorbehandelter Ratten. Zentralbl Bakteriol Hyg I Orig 198: 257- 260, 1965 .

56. Wenzel $\mathrm{M}$ and Eißner D: Die Verteilung ${ }^{51} \mathrm{Cr}$-markierter Clostridiensporen in Tumor-tragenden Ratten. Z Naturfosch 23B: 255-258, 1968.

57. Dietz O, Fabricius E-M, Kunde D, Schneeweiss U, Schröder E, Tudyka $G$ and Benedix A: Möglichkeiten einer serologischen Tumordiagnostik mit Klostridiensporen - erste Ergebnisse an Spontantumoren des Hundes und an AugentransplantatTumoren des Kaninchens. Mh Vet-Med 35: 689-694, 1980.

58. Bergère J-L: Mise en évidence de deux groupes sérologiques principaux chez Clostridium tyrobutyricum. Ann Institut Pasteur/ Microbiol 136B: 75-91, 1985.

59. Fabricius E-M, Benedix A, Schneeweiss U, Schmidt W and Streller B: Bestimmung der onkolysierenden Wirkung von Klostridien am Hamster-A Mel 3-Modell - eine quantitative Studie mit definierten Bewertungskriterien. Arch Geschwulstforsch 48: 538-551, 1978

60. Schau H-P, Fabricius E-M, Schneeweiss U and Benedix A: Untersuchungen zur Charakterisierung eines Clostridienstammes für die Krebsdiagnostik. Zentralbl Bakteriol I Abt Orig A 246: 80-97, 1980.

61. Stüssi DB: Beitrag zur Physiologie von Clostridium butyricum Prazm unter besonderer Berücksichtigung des ReduktionsOxydations-Potentials. Landwirtschaftliches Jahrbuch Schweiz 75: 576-632, 1961.

62. Fabricius E-M, Schmidt W and Schneeweiss U: The serological clostridium tumour test - application of discriminance analysis. Zentralbl Bakteriol Hyg A 263: 552-560, 1987.

63. Fabricius E-M, Schneeweiss U and Schmidt W: Methodological aspects of a serodiagnostic clostridium tumour test - experience with spontaneous canine tumours. Zentralbl Bakteriol Hyg A 265: 99-112, 1987.

64. Fabricius E-M, Dietz O, Schneeweiss U, Schmidt W, Wildner GP, Baumann G, Benedix A and Weisbrich C: Vergleichende Untersuchungen des Klostridien-Tumor-Tests an Hunden und Pferden. Mh Vet-Med 49: 151-157, 1994.

65. Wittmann W, Fabricius E-M, Schneeweiss U, Schaepe C, Benedix A, Weisbrich C and Schwanbeck U: Application of microbiological cancer test to cattle infected with bovine leucosis virus. Arch Exp Vet-Med 44: 205-212, 1990.

66. Fabricius E-M, Schneeweiss U, Schau H-P, Schmidt W and Benedix A: Quantitative investigations into the elimination of in vitro-obtained spores of the non-pathogenic Clostridium butyricum strain CNRZ 528, and their persistence in organs of different species following intravenous spore administration. Res Microbiol 144: 741-753, 1993.

67. Möse JR and Möse G: Tumornachweis durch Clostridienantikörper. Diagnostik 6: 53-56, 1973.

68. 12. Durchführungsbestimmung zur Prüfung von Arzneimitteln zur Anwendung in der Humanmedizin vom 17. Mai 1976. Gesetzblatt (DDR) 1976; I, Nr. 17: 248-251. 
69. Verfügungen und Mitteilungen des Ministeriums für Gesundheitswesen der DDR vom 21.08.1980. Richtlinien für die Prüfung von Seren, Impfstoffen und anderen Arzneimitteln zur Anwendung in der Humanmedizin vom 26. Juni 1980: 1-7, 1980.

70. Schneeweiss U, Fabricius E-M and Schmidt W: Conception and stages of development of the microbiological cancer test. Arch Geschwulstforsch 56: 401-405, 1986.

71. Fabricius E-M, Schneeweiss U, Dietz O, Tudyka G, Kunde D, Wildner GP, Schmidt W, Benedix A and Schubert E: Der Einsatz eines serologischen Klostridientestes in der Tumordiagnostik. Z Erkr Atmungsorgane 155: 292-304, 1980.

72. Fabricius E-M, Schneeweiss U, Schröder E, Dietz O, Wildner GP, Schmidt W, Baumann G, Benedix A, Weisbrich C and Stuhrberg U: Ergebnisse der serologischen Tumordiagnostik mit Klostridiensporen bei Hunden mit Spontantumoren. Mh VetMed 41: 220-224, 1986.

73. Dressel H, Benedix A and Schneeweiss U: Zur Pyrogenität von Clostridium butyricum. Pharmazie 40: 59-60, 1985.

74. Dinarello CA: Interleukin 1 and the pathogenesis of the acutephase response. N Engl J Med 311: 1413-1418, 1984.

75. Fabricius E-M, Schneeweiss U, Benedix A, Weisbrich C, Dietz O, Gütz H-J, Jacobasch K-H, Seifart W, Lübbe D and Wildner GP: Tumor diagnosis with the clostridium tumor test. In: Tumor Associated Antigens, Oncogenes, Receptors, Cytokines in Tumor Diagnosis and Therapy at the Beginning of the Nineties. Klapdor R (ed). Zuckschwerdt W, München, pp231$233,1992$.

76. World Health Organization Technical Report Series: Early detection of cancer. 422: 248-251, 1969.

77. van Heyningen WE and Mellanby J: Tetanus toxin. In: Microbial Toxins II A. Bacterial Protein Toxins. Kadis S, Montie TC and Ajl SJ (eds). Academic Press, New York, London, pp69$108,1971$.

78. Brooks VB, Curtis DR and Eccles JC: The action of tetanus toxin on the inhibition of motoneurons. J Physiol 135: 655-672, 1957.

79. Schneeweiss U, Fabricius E-M and Schmidt W: Tumorforschung am biologischen Modell. Fischer-Verlag Jena und Walter de Gruyter, Berlin-New York, pp336, 1980.

80. Schneeweiss U and Fabricius E-M: Biologische Besonderheiten der Tumorzelle und ihre Möglichkeiten für eine mikrobiologische Diagnose. Zentralbl Chirurgie 92: 1636-1644, 1967.

81. Mendelsohn ML: The growth fraction: a new concept applied to tumors. Science 132: 1496, 1960.

82. Schneeweiss U and Fabricius E-M: Immune phenomena of syngeneic, allogeneic, and xenogeneic transplantable tumours in relation to the quantitative tumour tetanus assay of the mouse. Ann Immunol 7: 23-34, 1975.

83. Skipper HE, Schabel FM and Wilcox WS: Experimental evaluation of anticancer agents. XIII. On the criteria and kinetics associated with 'curability' of experimental leukemia. Cancer Chemother Rep 35: 1-111, 1964.

84. Negelein E, Schneeweiss U and Fabricius E-M: In vitro effect of X-irradiation on respiration and glycolysis of Ehrlich-ascitic carcinoma cells of the mouse - an experimental comparison with the mouse tumour-tetanus assay. Arch Geschwulstforsch 49: 508-521, 1979.

85. Haddow A: Addendum to 'molecular repair, wound healing, and carcinogenesis: Tumor production a possible overhealing?' Adv Cancer Res 20: 343-366, 1974.

86. Bullock WE and Cramer W: On a new factor in the mechanism of bacterial infection. Proc Royal Soc B 90: 513-529, 1919.

87. Hewitt HB: The mechanisms of subcutaneous injection. Br J Exp Pathol 35: 35-40, 1954.

88. Schneeweiss U, Fabricius E-M and Schmidt W: Die Pathogenese der Tetanusinfektion im Subkutanmodell der Wundregeneration und des Tumorwachstums der Maus. Nova Acta Leopoldina NF 66: 145-159, 1991.

89. Schneeweiss U, Fabricius E-M and Schmidt W: Der mikrobiologische Krebstest - weiterführende Untersuchungen mit dem experimentellen Tumor-Tetanus und Wund-Tetanus der Maus. Z Experimentelle Chirurgie 12: 201-208, 1979.

90. Helpap B and Cramer H: Autoradiographische Untersuchungen über die bindegewebige Proliferation in Hautwunden. Res Exp Med 157: 289-299, 1972.

91. Schneeweiss U, Fabricius E-M and Schmidt W: Versuche zur Pathogenese von Tetanus-Sporen unter Berücksichtigung eukaryoter Zellsysteme. Zentralbl Bakteriol Hyg I Abt Orig A 243: 528-541, 1979.
92. Halberg F: Rhythmicity of fundamental biologic phenomena. Ann NY Acad Sci 231: 108-110, 1974.

93. Schewing LE and Pauly JE: Cellular mechanisms involving biorhythms with emphasis on those rhythms associated with the S and M stage of the cell cycle. Int J Chronobiol 1: 269-286, 1973.

94. Clausen OPF, Thorud E, Bjerknes R and Elgjo K: Circadian rhythms in mouse epidermal basal cell proliferation - variations in compartment, size, flux and phase duration. Cell Tissue Kinetics 12: 319-337, 1979.

95. Fildes P: Tetanus. VI. The conditions under which tetanus spores germinate in vivo. Br J Exp Pathol 8: 387-393, 1927.

96. Schmidt W, Schneeweiss U and Fabricius E-M: A new principle of specificity in anaerobic infections - mathematical model of mitosis-stimulated bacterial growth. The application of the tumor-tetanus phenomenon. J Theor Biol 86: 783-802, 1980.

97. Brüggemann H, Bäumer S, Fricke WF, Wiezer A, Liesegang H, Decker I, Herzberg C, Martínez-Arias R, Merkl R, Henne A and Gottschalk G: The genome sequence of Clostridium tetani, the causative agent of tetanus disease. Proc Natl Acad Sci USA 100: 1316-1321, 2003.

98. Brüggemann H, Wiezer A and Gottschalk G: Insights in metabolism and toxin production from the complete genome sequence of Clostridium tetani. Nova Acta Leopoldina NF 92: 95-99, 2005.

99. Shoesmith JG and Holland KT: The germination of spores of Clostridium tetani. J Gen Microbiol 70: 253-261, 1972.

100. Brüggemann H, Bauer R, Raffestin S and Gottschalk G: Characterization of a heme oxygenase of Clostridium tetani and its possible role in oxygen tolerance. Arch Microbiol 182: 259-263, 2004.

101. Kubitschek HE: The distribution of cell generation times. Cell Tissue Kinetics 4: 113-122, 1971.

102. Steel GG: Growth kinetics of tumours. In: Cell Population Kinetics in Relation to the Growth and Treatment of Cancer. Clarendon Press, Oxford, 1977.

103. Schneeweiss U, Schmidt W and Fabricius E-M: The role of cell population kinetics in the efficacy of penicillin - an experimental analysis and stochastic modelling of the tumour tetanus and wound tetanus of the mouse. Zentralbl Bakteriol Hyg I Orig A 266: 506-521, 1987.

104. Schneeweiss U, Schmidt W and Fabricius E-M: Antibacterial immunity and its modelling in experimental tumor tetanus and wound tetanus of the mouse. J Theor Biol 126: 15-32, 1987.

105. Altman A: Acute tumour lysis syndrome. Semin Oncol 28 (Suppl 5): 3-8, 2001

106. Minton N and Morris JG: Isolation and partial characterization of three cryptic plasmids from strains of Clostridium butyricum. J Genl Microbiol 127: 325-331, 1981.

107. Young M, Minton NP and Staudenbauer WL: Recent advances in the genetics of the clostridia. FEMS Microbiol Rev 5: 301-325, 1989.

108. Minton NP, Brehm JK, Swinfield T-J, Whelan SM, Mauchline ML, Bodsworth N and Oultram JD: Clostridial cloning vectors. In: The Clostridia and Biotechnology. Woods DR (ed). Butterworth-Heinemann Publishing, Boston, MA, pp119-150, 1993.

109. Schlechte H and Elbe B: Recombinant plasmid-DNA variation of Clostridium oncolyticum - Model experiments of cancerostatic gene transfer. Zentralbl Bakteriol Hyg A 268: 347-356, 1988.

110. Van Mellaert L, Barbé S and Anne J: Clostridium spores as anti-tumour agents. Trends Microbiol 14: 190-196, 2006.

111. Minton NP, Mauchline ML, Lemmon MJ, Brehm JK, Fox M, Michael NP, Giaccia A and Brown M: Chemotherapeutic tumour targeting using clostridial spores. FEMS Microbiol Rev 17: 357-364, 1995.

112. Liu S-C, Minton NP, Giaccia AJ and Brown JM: Anticancer efficacy of systemically delivered anaerobic bacteria as gene therapy vectors targeting tumor hypoxia/necrosis. Gene Ther 9: 291-296, 2002.

113. Minton NP: Clostridia in cancer therapy. Nat Rev Microbiol 1: 237-242, 2003

114. Brown JM, Liu S-C, Giaccia AJ and Minton NP: Anaerobe targeted enzyme-mediated prodrug therapy. United States Patent 6, 984,513 B2, Jan 10: 1-29, 2006.

115. Theys J, Nuyts S, Landuyt W, Van Mellaert L, Dillen C, Böhringer M, Dürre P, Lambin P and Anné J: Stable Escherichia coli - Clostridium acetobutylicum shuttle vector for secretion of murine tumor necrosis factor alpha. Appl Environ Microbiol 65: 4295-4300, 1999. 
116. Nuyts S, Van Mellaert L, Theys J, Landuyt W, Lambin P and Anné J: The use of radiation-induced bacterial promoters in anaerobic conditions: a means to control gene expression in Clostridium-mediated therapy for Cancer. Radiat Res 155: 716-723, 2001.

117. Nuyts S, Van Mellaert L, Theys J, Landuyt W, Lambin P and Anné J: Clostridium spores for tumor-specific drug delivery. Anticancer Drugs 13: 115-125, 2002.

118. Lambin P, Theys J, Landuyt W, Rijken P, van der Kogel A, van der Schueren E, Hodgkiss R, Fowler J, Nuyts S, de Bruijn E, Van Mellaert L and Anné J: Colonisation of Clostridium in the body is restricted to hypoxic and necrotic areas of tumours. Anaerobe 4: 183-188, 1998.

119. Theys, I, Landuyt W, Nuyts S, Van Mellaert L, Bosmans E, Rijnders A, Van Den Bogaert W, Van Oosterom A, Anné J and Lambin P: Improvement of Clostridium tumour targeting vectors evaluated in rat rhabdomyosarcomas. FEMS Immunol Med Microbiol 30: 37-41, 2001.
120.Dang LH, Bettegowda C, Huso DL, Kinzler KW and Vogelstein B: Combination bacteriolytic therapy for the treatment of experimental tumours. Proc Natl Acad Sci USA 98: 15155-15160, 2001.

121. Bettegowda C, Dang LH, Abrams R, Huso DL, Dillehay L, Cheong I, Agrawal N, Borzillary S, McCaffery JM, Watson EL, Lin KS, Bunz F, Baidoo K, Pomper MG, Kinzler KW, Vogelstein B and Zhou S: Overcoming the hypoxic barrier to radiation therapy with anaerobic bacteria. Proc Natl Acad Sci USA 100: 15083-15088, 2003.

122. Agrawal N, Bettegowda C, Cheong I, Geschwind JF, Drake CG, Hipkiss EL, Tatsumi M, Dang LH, Diaz LA Jr, Pomper M, Abusedera M, Wahl RL, Kinzler KW, Zhou S, Huso DL and Vogelstein B: Bacteriolytic therapy can generate a potent immune response against experimental tumors. Proc Natl Acad Sci USA 101: 15172-15177, 2004. 